\title{
Prevalence of coccidiosis in broiler-chicken farms in the Kerbala and Babylon provinces ,Iraq
}

Dhamiaa Make Hamza* ; Zuhair Muhammad Ali Jeddoa* and Hadi Rasol Hasan AlMassodi $^{\text {** }}$

*Collage of Medicine ,University of Kerbala,Iraq.**Collage of Pharmacy ,University of Kerbala,Iraq

Email :dhamiaam@yahoo.com

\section{Received:-17/2/2015}

\section{Accepted:-5/4/2015}

\begin{abstract}
Coccidiosis is an intestinal disease of chickens caused by various species of protozoan parasites within the genus Eimeria. Diagnosis and genetic characterization of different species of Eimeria are central to the prevention, surveillance, and control of coccidiosis. The aim of the present study was to identified different poultry Eimeria species that considered the causal agents of poultry coccidiosis in each of the Kerbala and Babylon provinces.
\end{abstract}

The present study observations were revealed platuation ( increasing and decreasing) the percentages of infection with coccidiosis during different months of a year and that due to the large change in temperature and humidity in Iraq,

A lot off 200 samples of feces and intestines were collected from chickens that suspected infection with coccidiosis during the period from August 2013 to July 2014 and the results revealed that 160 samples were positive depending on the macroscopic and microscopic examination Which diagnosed three species of Eimeria includes E.tenella which formed the largest proportion of the total positive samples (66.8\%) then the species E.necatrix which accounted for (30\%) and finally the species E.maxima which form $(3.13 \%)$.

The results showed that the highest percentage of infection in both of Kerbala and Babylon provinces were in December (23.12\%) and the lowest percentage in July $(1.87 \%)$.

Key words: Poultry Coccidiosis, Eimeria,Macroscopic, Microscopic examination

Physiology Classification QR1-502-71 


\section{Introduction}

morphometry of their sporocysts and oocysts as well as their patterns of development, and assessing the site and extent of the pathological lesions in the intestine of chicken $(6,7)$. However, these methods are costly, time-consuming, require skilled personnel and can be unreliable under the circumstances of mixed field infections, particularly when the overlap in biological and morphological characters makes the unequivocal identification and differentiation of Eimeria species difficult $(8,9)$.

The number of studies related to the presence of chicken Eimeria species in Iraq are limited. These studies have been conducted in few locations and species identification was depended on the oocysts morphology, necropsy and/or histopathological findings. And as a result, nine Eimeria species (E.acervulina, E. brunetti, E. hagani, E. maxima, E. mitis,E. mivati, E. necatrix, E. praecox and E. tenella) have been reported to found in chickens $(10,11)$.

In this study, we aimed to identify the Eimeria species causing coccidiosis in

macroscopic and microscopic examination.

\section{Materials and Methods}

\section{1- Sample collection}

\section{2- Direct examination method (microscopic examination):}

The first step in the present study is identified the positive samples from whole samples that collected from suspected chickens with coccidiosis and by
Avian coccidiosis is one of the most important diseases affecting the intensive poultry industry worldwide. Coccidia are almost universally found wherever chickens are raised and it is exceedingly rare to Find a commercial chicken flock not affected. The infection causes tissue damage in the intestinal tract leading to interruption in digestive processes, blood loss, and increased susceptibility to other diseases, subclinical enteric infection, and sub acute mortality(1). The disease is controlled by the inclusion of anticoccidial drugs in the feed or vaccination $(2,3$,). There are nine commonly recognized species of chicken coccidia; Eimeria acervulina, E. brunetti, E. maxima , E. mitis, E. necatrix,E. praecox , E.mevati ,E.hagani and E. tenella. Each Eimeria species develops in a particular location within the chick digestive tract with some overlap seen between species(4).

The specific identification of Eimeria species and strains is important for diagnosis and control, as well as for epidemiology and population biology studies (5).Traditionally, Eimeria species have been identified by morphology and/or broilers by depending on clinical symptoms and through using of

From August 2013 to July 2014 about 200 samples of fresh fecal droppings and intestines were collected from suspected infected chickens with coccidiosis attending to the veterinary hospital and veterinary clinics were spread in Kerbala and Babylon provinces for the examination and treatment . 
which concentrated $10 \%$ or by staining the samples wit Iodin or Giemsa stain to made the internal components of the Eimerian oocysts clear (12).

\section{Results}

water consumption, depression, weight loss and reduced egg production .

The results of macroscopic examination of the present study has been showed presence of acute hemorrhage in the ceca which will either be liquid or Coagulated and the wall of ceca appeared dark similar to black color as the fig. (1), while the intestines may contained a large amount of blood and without any nutrients due to loss of appetite during the get infection, while the other macroscopic signs observed in other cases, the thickness of the walls of the intestines with swollen (Ballooning), Congestion, having inky bleeding ,mucoied exudation and the intestinal content had a reddish colure as seen in the figure(1). examined microscopically to

determined the oocysts either by direct methods in cases of acute diarrhea in which the samples examined either freshly or used of a natural formalin buffer solution

Initial examination of chickens infected with coccidiosis by using of traditional techniques which include clinical ,macroscopic and microscopic examination that showed a large amount of Eimerian oocysts. Although the main notes during present study showed the prevalence of three species of chickens in both provinces that species are Ross 308, Hubbard and Cobb.

It was also observed that the predominant age in infected chickens ranging from two weeks to three weeks ,but the most clinical signs important in diagnosing is the growth rate decreased in infected birds, severe diarrhea, high mortality rate, a decrease in the proportion of feed and

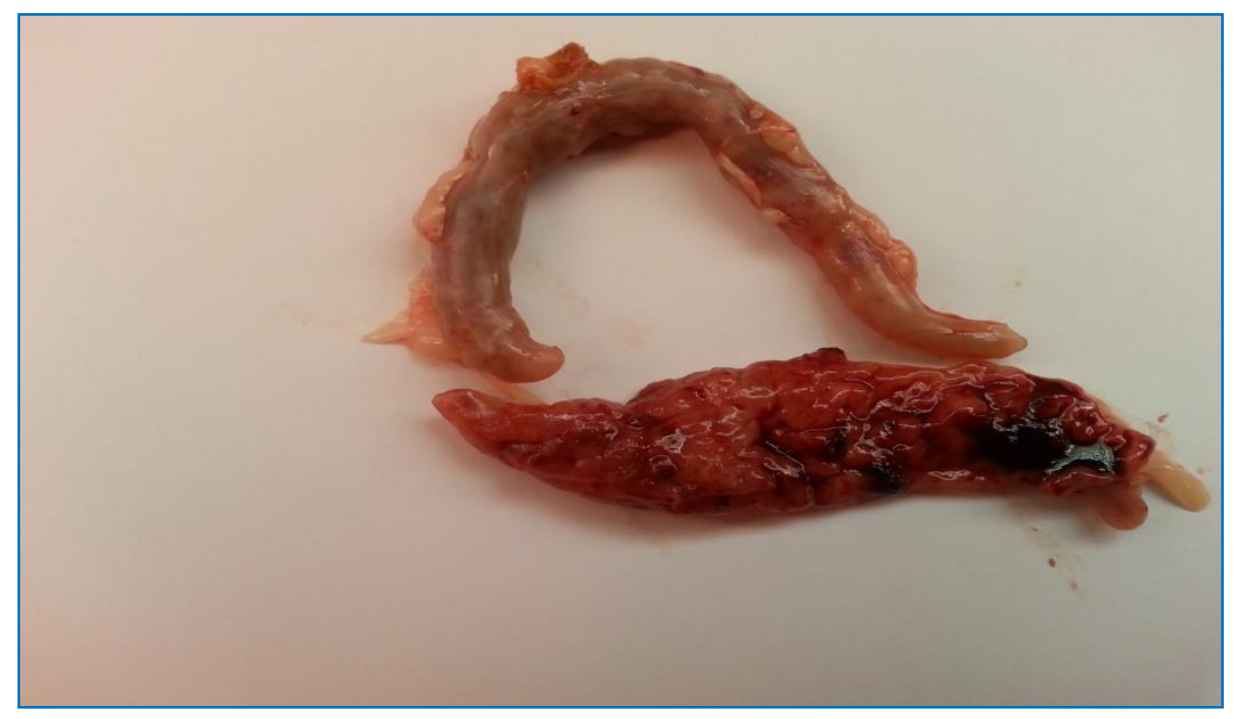


Figure(1): The isolated ceca from chicken infected with coccidiosis where they appear filled with bloody fluids

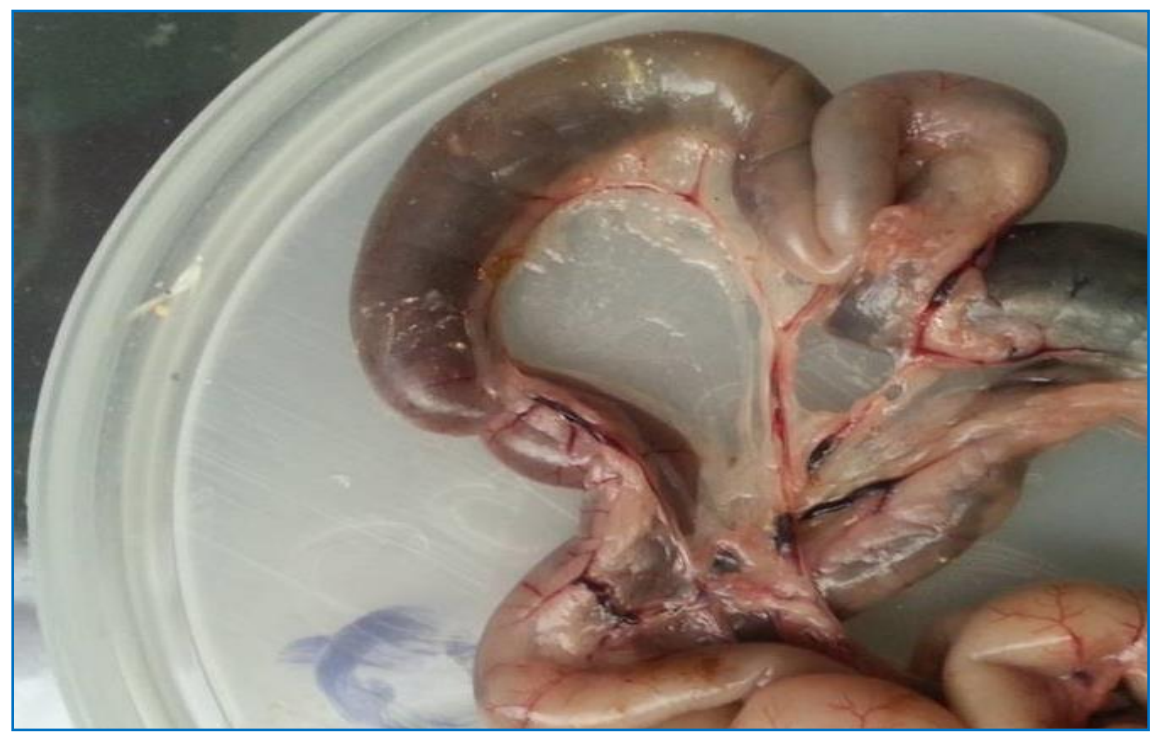

Figure(2): The Gut isolated from chickens infected with coccidiosis where noted the Swelling (Ballooning) and congestion in the middle part .

place it on a slide and examined by light microscope under magnification power $\times 40$ )to diagnosed the Eimerian oocysts which appeared in large numbers such as in the figure (3).

For microscopic examination the swabs were prepared from ceca and intestines, especially from areas that had suffer histological changes by scraping the mucous membrane and

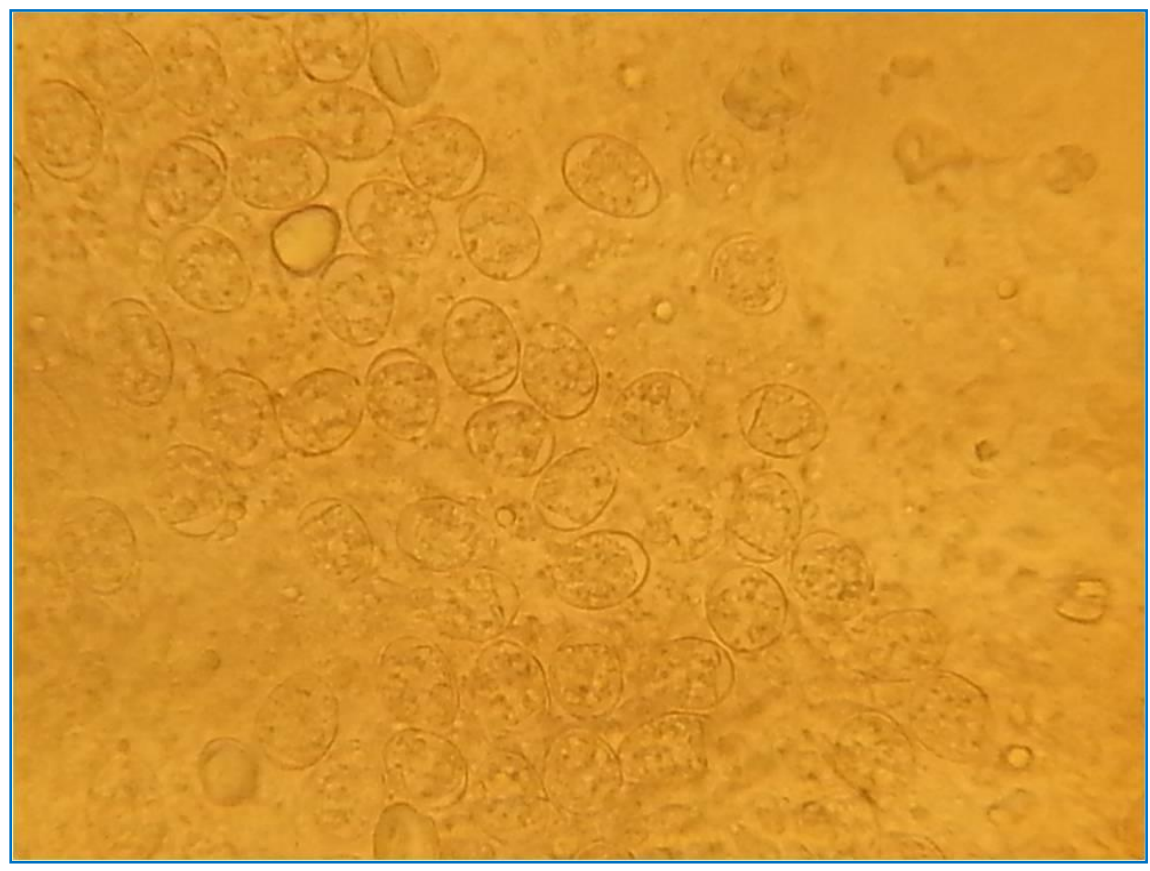


Figure(3): The Eimerian oocysts in the light microscope (X40).

many cases of infection with ciccidiosis recorded in the present study and through all was in the December (23.12\%) and the lowest rate was in the of July (1.87\%) as in the table (1).

Although all fields subject to the a regular agenda of vaccinations, but months of the year but the Proportion of infection differs between months, so the highest percentage of infection

Table(1): The percentage of infection with coccidiosis within months in each of the Karbala and Babylon provinces during the period (August 2013 - July 2014).

\begin{tabular}{|c|c|c|c|}
\hline Month & $\begin{array}{c}\text { No.of } \\
\text { isolated } \\
\text { samples }\end{array}$ & $\begin{array}{c}\text { No.of } \\
\text { positive } \\
\text { samples }\end{array}$ & $\begin{array}{c}\text { Percentage } \\
\%\end{array}$ \\
\hline August & 9 & 7 & 4.37 \\
\hline September & 10 & 10 & 6.25 \\
\hline October & 14 & 10 & 6.25 \\
\hline November & 25 & 24 & 15 \\
\hline December & 44 & 37 & 23.12 \\
\hline January & 29 & 24 & 12.5 \\
\hline February & 23 & 23 & 14.37 \\
\hline March & 19 & 9 & 5.62 \\
\hline April & 5 & 4 & 2.5 \\
\hline May & 10 & 8 & 5 \\
\hline June & 7 & 5 & 3.12 \\
\hline July & 5 & 3 & 1.87 \\
\hline Total & 200 & \multicolumn{2}{|c|}{160} \\
\hline
\end{tabular}

Depending on the site of infection with coccidiosis in the chickens,morphological featurea of oocysts and by measuring of the isolated oocysts by used of Ocular micrometer ,so, three species of
Although ease diagnosed of the oocysts in the feces microscopically, but so difficult to specific determined of species that responsible for poultry coccidiosis . 


\section{Al-Qadisiyah Journal for Pure Science year2018

the table (2).

Eimeria were identified ,E.tenella

,E.necatrix and E.maxima as shown in

Table (2): The percentage of the three species of Eimeria diagnosed in Karbala and Babylon provinces:

\begin{tabular}{|c|c|c|}
\hline Species & Positive samples & $\begin{array}{c}\text { Percentage } \\
\%\end{array}$ \\
\hline E.tenella & 107 & 66.8 \\
\hline E.necatrix & 48 & 30 \\
\hline E.maxima & 5 & 3.13 \\
\hline Total & $\mathbf{1 6 0}$ \\
\hline
\end{tabular}

compared with other months and August was shown lower (1.87\%), and that due to that the oocyst of Eimeria for require high amount of humidity (floor wetness) an low temperatures degree( essential for oocyst sporulation and survivability), so the results of present study In agreement with studies occurred in Several countries like the research occured in Iran which conclude that the Eimerian species were higher in July (94.4\%) compared with other months and June was shown lower $(57.9 \%)$. But, level of OPG was shown higher in summer season (July, August; over $40 \%$ ) than that of winter season (January, February; 23.1\%, $16 \%)(14)$.

In Iraq- Ninevah the researchers found that the percentage of infection variant in different months, the highest, 80\% during March and the lowest during October $11.11 \%$ ( 15).

In Nigeria the researcher found in his epidemiological study that the highest rate of infection among chickens with coccidiosis during the rainy seasons specially during March (16).

\section{Discussion}

In chickens is clearly central to a better understanding of epidemiology and dynamics of the disease in intensive and extensive chicken establishments. This is particularly important for planning an effective prevention and control program of coccidiosis.Traditionally, diagnosis has been achieved by detecting Eimeria oocysts excreted in the feces of chickens by measuring oocyst and sporocyst size or notes of the site and pathological lesions in the intestine of chickens. Although the microscopic examinations can absolutely show the positive fecal samples, but the traditional methods very limited in the specific diagnosis or identification of Eimeria species also These methodes are unreliable in mix infection when there are a multiple species of Eimeria infect a single host and there is Similarity in the size, shape of oocysts and the sites of infection (13).

The monthly prevalence of Eimeria infection in both provinces was shown higher in July $(23.12 \%)$ 


\section{Al-Qadisiyah Journal for Pure Science year2018

percentage of infection was E.tenella (66.8\%), then E.necatrix which form $(30 \%)$ and finally the species E.maxima $(3.13 \%)$.

The study occurred in north west of Iran recorded five species of Eimeria and thes species were E.tenalla (14.22\%) , E.acervulina $(23.58 \%)$,E.maxima (5.5\%) and E.mitis (2.29\%) (18) .

The surveyed farms were previously affected by coccidiosis in different seasons reflects the size of the problem. That all the farms had anticoccidials in the feed indicates the failure to control the disease using chemoprophylaxis under the rearing practices. This might be due to misuse of coccidiostat (dose or improper mixing in feed) or to the development of resistance of local strains of Eimeria to available compounds(14).

\section{References}

fowl Avian Pathol, 27, 613617.

4- Woods, WG ; Whithear, KG; Richards , DG.; Anderson , GR. ; Jorgensen, WK., Gasser , RB . (2000) : Single strand restriction fragment length polymorphism analysis of the second internal transcribed spacer ( ribosomal DNA ) for species of Eimeria from chickens in Australia. Int JParasitol, 30, 1019-1023.

5- Morris ,GM; Gasser, RB (2006): Biotechnological advances in the diagnosis of avian coccidiosis and theanalysis of genetic variation in Eimeria. Biotechnol Adv,24, 590-603.

6- Aarthi ,S; Dhinakar ,Raj G; Raman, $\mathrm{M}$;Gomathinayagam,

$\mathrm{S}$;
The results revealed the prescience of three of Eimeria species in chickens and the most common species which represent the highest

To compare between the results of this study and other the results of other studies, the same study done in AlHamdania region-Ninevah and The results revealed the prescience of eight of Eimeria species in broilers these species were: Eimeria tenella(32.17\%); E.necatrix (16.83\%) ; E.maxima (11.38\%); E.mivati $(11.38 \%$ ); E.mitis (1.98\%) ; E.brunetti (11.88\%); E.acervulina $(5.44 \% \quad)$; E.praecox (7.92\%). The total percentage of broiler coccidiosis was $45 \%(15)$.

In Jordan the epidemiological study about the chicken coccidiosis revealed the spreading of three species of Eimeria thes species were E.tenella $(39 \%)$, E.necatrix $(12 \%)$ and E.brunetti(12\%) (17).

1-Schwarz, RS.; Jenkins, MC.; Klopp ,S.; Miska, KB. (2009): Genomic analysis of Eimeria spp. populations in relation to performance levels of broiler chicken farms in Arkansas and North Carolina. J. Parasitol, 95, 871-880.

2- McDougald, LR. (2003): Protozoal infections. 973-1023. In: YM , Saif; HJ., Barnes; JR., Glisson; AM., Fadly; LR. McDougald; DE ., Swayne (Eds).

Diseases of Poultry. Iowa State Press, Ames 973- 990Pp.

3- Thebo, P; Lunden A; Uggla, A; Hooshmand-Rad, P. (1998): Identification of seven Eimeria species in Swedish domestic 
the council of college of edu.for pure Sciences of Karbala in partial fulfillment of the Requirements for degree of Doctor of Philosophy in Biolgy /parasitology.

13- Damer, P. ;Blake, Zonghua Qin ; Jianping, Cai \& Adrian, L. Smith Enteric Immunology Group , Institute for Animal Health , ComptonBerkshire, RG20 7NN, UK.(2008). Development and validation of real- time polymerase chain reaction assays specific to four species of Eimeria. Avian Pathology . 37(1), 89_94.

14- Hadipour, M. M.; Ahad ,O.,. Mohammad ,N.; Fariborz ,A.and Omid ,N.(2011). Prevalence of Eimeria species in scavenging native chickens of Shiraz, Iran. African Journal of Microbiology Research Vol. 5(20), pp. 3296-3299

15-ALNeema ;M.S.S. and A.F. ;Al-

Taee.(2012). Incidence of

Eimeria spp in broilers in Al-

Hamdania region-

Ninevah.Iraq.vet.J. Univercity of Mosul. 26:(201-206).

16-Etuk ,E.B; Okoli, IC \& Uko, MU. (2004).Prevalence and management issues associated with poultry coccidiosis in Abak Agr icultural Zona of Akwa Ibom State,Niger ia. Intern. Jour. of Poult. Scie.;3(2):135-139.

17-Al-Natour, MQ;Suleiman, MM.; Abo-Shehada,

MN.(2002).Flock- level prevalence of Eimeria species among broiler chicks in northern Jordan.Preve. Vet. Med.;53(3) :305-310.
Kumanan ,K. (2010):

Molecular prevalence and preponderance of Eimeria spp.Among chickens in Tamil Nadu, India. Parasitol Res, 107, 1013- 1017.

7-Johnston, W.; Shirley, M., Smith, A. \& Gravenor, M. (2001).

Modelling host cell availability and the crowding effect in Eimeria infections. International Journal for Parasitology, 31, 1070_1081.

8-Carvalho ,FS; Wenceslau ,AA; Teixeira, M; Matos Carneiro, JA; Melo ,AD; Albuquerque, GR. (2011):Diagnosis of Eimeria species using traditional and molecular methods in field studies. Vet Parasitol, 176, 95-100.

9-Suhair, R.; Al-Idreesi , Mahmoud Kweider and Mahmad, M. Katranji.(2013).Efficacy of Eimeria tenella (Oocyst and Sporozoite) Proteins as a Vaccine in Broilers Against occidiosis.International Journal of Poultry Science 12 (3): 157 163.

10- Demir, S. (1992): Bursa bölgesi tavuklarında coccidiose etkenleri vebunların yayılışı. Uludağ Univ Vet Fak Derg, 122,45-49.

11- Karaş GD. (2004): Etlik piliçlerde canlı aşı uygulamalarının koksidiyozdan

korunmadaki etkisinin araştırılması.

Unpublished doctoral

Dissertation . University of Ankara,Turkey.2, 143- 51.

$12-$

Mushattat,Sukayna J.(2013).Parasitology and Immunology study Gastrointestinal parasites in Chickens.Athesis Submitted to 
Tabriz (Northwestern of Iran).MunisEntomo. and Zool. 4(1) :53-58.
18-Nematollahi, A; Moghaddam, Gh ;

Pourabad,

$\mathrm{RF}$.

(2009).Prevalence of Eimeria species among broiler chicks in

انتثار الخمج بداء الاكريات في حقول الاجاج في كل من محافظتي كربلاء وبابل

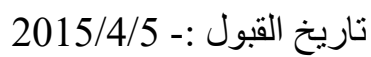

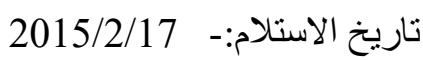

\section{الخلاصة}

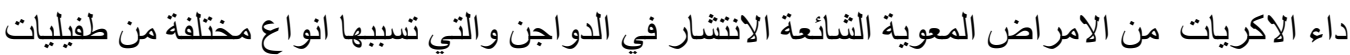

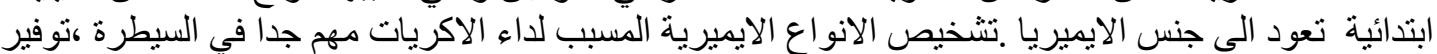

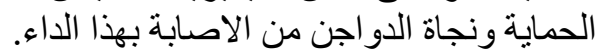

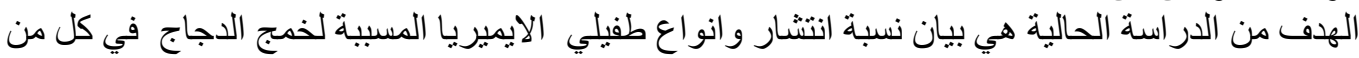

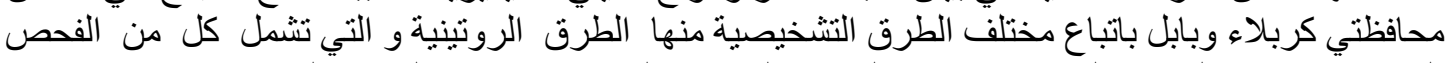

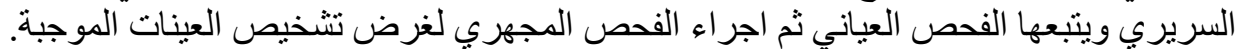

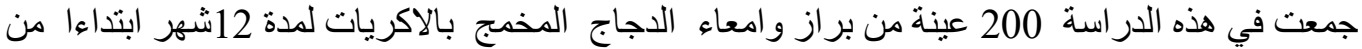

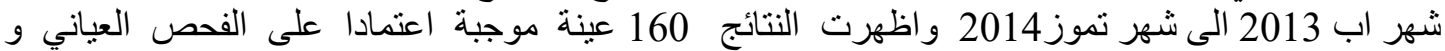
المجري وتم تثخيص ثلاثة انواع من الايميريا المخمجة للاجاج في كل من محافظتي كربلاء وبابل وهي اعني

. E.maxima $(3.13 \%)$, E.necatrix $(30 \%)$, E.tenella $(66.8 \%)$ مفتاح الكلمات :الايميريا ،داء الاكريات ،الفحص العياني ،الفحص المجهري 